\title{
Two Roads to Nowhere: Appraising Thirty Years of Public Administration Research
}

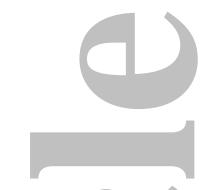

\author{
B. Guy Peters, University of Pittsburgh \\ Jon Pierre, University of Gothenburg
}

The celebration of the $30^{\text {th }}$ anniversary for this journal is a good opportunity to reflect on the development of public administration research during this time period. This brief essay will argue that much of current public administration research falls into one of two different approaches, one of which offers an almost completely theoretical analysis of public institutions whereas the other delivers largely atheoretical analyses. Neither of these two approaches is able to deliver a contribution to public administration as an academic discipline. Such contributions, we suggest, can only come from theoretically informed empirical study of the practice of public administration. Or, as Christopher Pollitt has argued, public administration needs to return to thinking about the "big picture" rather than the fragments that dominate much of the contemporary work in the discipline (Pollitt, 2016).

One approach is populated by scholars with only very marginal attention to empirical detail, values or institutional complexities. Instead, this approach builds on deductive rational choice or public choice theory where public institutions are seen as arenas for utility-maximizing public servants and managers. Much of this literature reads as if the author had never been visited a public organization, other than perhaps to get a driver's license, and certainly had not spent any time observing closely what happens in those organizations and how real world public administrators practice their craft.

The other approach embraces the complexities and ambiguities of public sector organizations and their staff, so much so that it fails to either use theory to make sense of their empirical data or display a lack of interest in discussing their findings in more generalizable terms. Research drawing on this approach will generate in-depth case studies with only scant attention to the degree to which results challenge our conceptual understanding of the issues under scrutiny. The absence of theory here may not be so much managerial theories as a concern with the inherently political nature of public administration. Especially with the emphasis on management in public administration during the past several decades, it may be easy to forget that these organizations are embedded in a political context.

The disappointing outcome of this state of affairs is that neither of the two dominant strands of research is conducive to an understanding of real-world public administration in a conceptual and empirical perspective. Both fail in confronting theory with empirical observation. Both fail in fostering public administration research that advances public administration as an academic discipline while at the same time engaging stakeholders, bureaucrats or managers. And, most importantly, both fail bitterly in observing public administration from the perspective of normative theory and the role values have in shaping an organizational identity.

These perceived failings also help to point out the fundamental nature of public administration as lying, at times uncomfortably, between the world of academe and the world of practice. On the one hand public administration is an academic field, or perhaps even an academic discipline, and must therefore conform to the canons of scholarship. Those canons demand

This is the author manuscript accepted for publication and has undergone full peer review but has not been through the copyediting, typesetting, pagination and proofreading process, which may lead to differences between this version and the Version record. Please cite this article as doi:10.1111/ gove.12229. 
that some attempts to build broader theoretical understandings be linked to reliable information and empirical observation.

On the other hand, scholars in public administration are working in an area with important implications for practice. If our research and writing can improve the performance of the public sector-in either efficiency or democratic terms - then there is some obligation to consider those implications and attempt to engage with the "real world". But not to do so to excess, and forget that our added value is that we are able to stand somewhat apart from the daily demands of practice and ask broader and perhaps ultimately more important questions about how to deliver public services.

This unfortunate division of public administration into two divergent paths was not always the câse. For many years, students of public administration worked on the assumption that public organizations displayed crucial normative and institutional features that set them apart from other organizations. It was believed that members of these organizations were socialized into the norms, roles, symbols and ideals — what is referred to as a public service ethos- thus maintaining and reproducing these distinctive features of public organizations. ${ }^{1}$ Recruitment was to some degree a matter of self-selection where a passion for serving the public interest led some to seek employment in the public sector. Wilsonian and Weberian notions about loyalty, hierarchy, institutional integrity and professionalism provided a normative framework which embedded public bureaucracies and public servants. Kaufman, Wilson, Simon, Selznick, Olsen, Waldo and other students of public administration understood that we cannot make sense of public administration without considering these essential features of the bureaucracy and, indeed, of the state.

Our point here is not that everything was better in previous years. Rather, we argue that unlike most other academic disciplines where the past several decades have seen substantive progress in aligning theory with empirical inquiry to the benefit of both, public administration appears to have developed from "a discipline in search of a subject matter" (Waldo, 2007 [1948]) to a bifurcated academic field with an almost complete disconnect between theory and empirical analysis.

One rather obvious example of the divergence between theoretical development and empirical analysis is in the relative lack of use of institutional theory by public administration. Despite the significant developments in this field (see Peters, 2011), and the public bureaucracy being a major institution in the public sector, and operating in a field composed of other institutions (Dimaggio and Powell, 1987) very little has been done to use this large body of theory to address the structure and performance of the bureaucracy.

Most of the research using institutional theory has been in comparative politics and in public policy, but very little use has been made of it in public administration. That has been true despite the interest in major structural changes in the public sector, such as the creation of administrative agencies, with those structural changes being accompanied by attempts to alter institutional values through increased politicization.

Dichotomizing a research field as heterogeneous as public administration is bound to cause some collateral damage. There are certainly scholars who escape both empiricism and deductive theoretical excesses. Leading scholars in public administration such as Christopher

\footnotetext{
${ }^{1}$ In contemporary public administration the study of "public service values" mirrors some of these concerns. See Perry (1996, 2000) and Vandenabeele, Brewer and Ritz (2014).
} 
Hood, Geert Bouckaert, Christopher Pollitt, Don Kettl, Paul t'Hart, Alasdair Roberts and H. George Fredrickson - to name but a few of the more prominent—have been able to combine detailed empirical analysis with concerns about empirical and normative theory, insisting that public administration must concern itself with the normative dimensions of its study object such as functionality, competence, loyalty, public interest, accountability and transparency.

A very useful understanding of this "third road" is provided in a collection of short essays in Governance addressing the question of whether contemporary public management research has neglected the State (Milward et al 2016). These essays address a number of the issues that concern us about the direction of research in our field, especially the loss of connection between fundamental political issues and public administration. Further, these essays point out the extent to which, after pioneering work in broadly comparative administration by scholars such as Fred Riggs and Ferrell Heady, our concerns have again narrowed to the advanced industrial systems where some of the ideas of public management may be possible to implement.

This brief essay does not attempt to review the huge literature on public administration. Instead we will only be able to discuss some principal examples of the two main approaches and also a few cases of research where theory and empirical study inform each other. Our concern is that with a growing amount of PA research falling into one of these two paths, the research field as a whole may over time become even less of a truly academic discipline: that is, a research field that displays a dynamic interplay between theory development and empirical inquiry.

\section{The deductive public choice road}

Some scholarship in public administration has been utilizing deductive public choice theory for some decades. The clearest example was the work of William Niskanen (1971) on the maximizing behavior of bureau chiefs. The argument that the leaders of public organizations would attempt to maximize their budgets was derived from good economic assumptions, as well as conventional stereotypes of the public bureaucracy. The problem is that there is almost no empirical support for the argument (see Blais and Dion, 1992).

The same problem occurred when public choice theory and agency theorists predicted that bureaucrats would "shirk" as soon as they saw greater utility to be derived from that option compared to work. While no empirical research was undertaken to see whether the theory could be confirmed, the idea of the "shirking bureaucrat" became a popular construct among this group of scholars (Peters and Pierre, 2015). Brehm and Gates (1997) decided to empirically test the "shirking" argument. Drawing on an impressive data set collected at all levels of the US government, they concluded that "the assumption that subordinates necessarily prefer shirking over working is unnecessarily simplistic... Workers will prefer producing some outputs over other outputs; they don't necessarily shirk at every opportunity" (Brehm and Gates, 1997:43, italics in original; see also Dilulio and Dilulio, 1994; Wilson, 1989). The ultimate irony is that Brehm and Gates' study has become somewhat of a standard reference for those who argue in support of the shirking thesis.

The problem here is that statements are logically deduced from an overarching assumption which may or may not be true. Testing the accuracy or validity of that assumption or the statements that are derived from that assumption is apparently not a matter of any concern. 
However, if the fundamental assumption is not a valid abstraction of reality then everything that follows will be equally incorrect, regardless of the quality or logic or the deduction. What was true for Niskanen is also true here. A negative, but largely unsubstantiated, assumption about the behavior of public administrators becomes enshrined in mathematics and therefore becomes "true".

\section{The practice-driven atheoretical road}

The other approach to public administration is characterized by excessive attention to empirical detail coupled with a minimum of interest to conceptual or theoretical issues.

Research is typically conducted as inductive case studies. The overall theme of these studies ranges from evaluations of organizational aspects of public administration to the specific handling of administrative matters. Often, and perhaps not surprisingly, these papers have problems finding their way into journals and may end up as entries in a report series. This is however often not seen as a problem as the author and his/her institution strongly emphasize engagement and relevance; objectives which are presumed to rule out references to theory and abstract analysis.

There are several different drivers of this type of public administration research. One such driver is government, for instance when policy-making institutions commission public administration experts to conduct a study of some specific aspect of a public sector organization as part of the knowledge-gathering in the early stages of the policy process. Furthermore, much of the research funded by grants from agencies or other administrative institutions tends to fall into this category mainly because the utility dimension of the research is strongly emphasized, or is assumed to be what the funders want.

The common factor here is the close linkage between the academy, particularly professional schools emphasizing relevance, engagement and the utility aspect of research, and the public bureaucracy. Commissioned research is not expected to report extensive analyses of conceptual or theoretical nature but should mainly "give us the numbers". Such research is saluted by the academic institutions as it helps further strengthen the bonds between schools and the real world of administration.

Another driver of this highly empirical public administration research can be related to the intellectual shift from public administration to public management which meant that much of the normative aspects of administration were virtually eliminated from the research agenda. There was a fundamental normative stance (generally unstated and unexamined) that management, and the efficiency assumed to be related to management, was the fundamental problem for public administration. This emphasis on a single value, and one that may be questionable for the public sector, left public administration somewhat lacking in its ability to provide insights into many issues of governance.

\section{The absence of normative theory}

Both the deductive and the empiricist schools of public administration tend to fail when it comes to analysis of the roles of norms and values in public administration. Theorists are simply not interested in the public service ethos or its constituent values. In their analysis, public servants are solely guided by expected utility. Agency theory, or the "new economics 
of organization", explicitly aims at "reducing complexity and apparent randomness" (Moe 1991:120). The idea that public organizations draw on and reproduce values such as the public interest or a desire to make a contribution to society is not compatible with that theory. Ideas, social norms and public sector values are seen as part of the complexity that has to be reduced in order for the model to work.

Scholars with an overwhelming interest in empirical detail, too, tend to be oblivious of normative theory, as they are of essentially all more general issues pertaining to public administration. This group of scholars could have studied the impact of social and organizational norms on the conduct of administration but such analyses are unfortunately extremely rare.

Ignoring the significance of the values that characterize public administration is to miss what sets public bureaucracies apart from other organizations. Deeply aware of how such norms and values shape intra-organizational behavior, Selznick (1957) would probably have argued that ignoring those aspects it would be to confuse an institution with an organization. To him, institutions are created by infusing a structure with values (Selznick, 1957). Those values create an organizational self, an identity. In addition to those fundamental values, there are also norms and values that prescribe administrative conduct in the politically embedded public bureaucracy such as loyalty and accountability. These values provided the foundation for Wilson and Weber's seminal analyses of public administration which continue to define the modus operandi of public servants. Our conclusion here is that theories that treat public administration as a set of generic organizational structures simply are not up to the task of making sense of public administration in any meaningful sense. They will miss what makes these institutions different from other institutions. The same problem applies to atheoretical, in-depth descriptive analysis of administrative practices.

\section{The Road Less Travelled}

What we are advocating, and what we hope we practice, is an approach to public administration that can combine an attention to theory and generalization with some understanding of how public administrators operate in situ. Since we have begun this section with a literary allusion to a poem by Robert Frost, perhaps we should continue by paraphrasing Alexander Pope to argue that the proper study of public administration is public administration. That is, if we want to understand public administration we need to do so through observing closely, as well as using modes of analysis and theories that are appropriate to the subject.

This simple plea concerning the future of public administration research should not be taken to be quite as retrograde as it may appear to some. There is certainly a place for deductive theorizing about the public bureaucracy and the behavior of individuals within it. We should remember that Max weber's original model of the bureaucracy was an ideal type rather than a grounded theory. We are only arguing that the theories from which those deductions are made should be directly relevant to the subject at hand. Both the academic understanding of the public bureaucracy and the practice of public administration would benefit from a closer relationship between the deductive models and the reality of administration.

We are suggesting that we need to rediscover the close linkage between dedutctive theory and empirial inquiry and how both benefit from strengthening that linkage. We need theory, 
deductive or otherwise, and we need the empirics to test the theory, and we need some attention to the norms governing practice. Public adminstration, like other areas of enquiry such as engineering, law, and social work, has both an academic and a practical dimension. As much as we may become absorbed in the academic niceties, we must keep one eye on the need to make public administration function in a real world that has numerous normative as well as efficiency concerns. An emphasis on management has been one way to address the practical dimension of public administration, but so many other relevant dimensioons have been lost.

\section{References:}

Blais, A. and S. Dion (1990), “Are Bureaucrats Budget Maximizers? The Niskanen Model and Its Critics", Polity 22(4): 655-74.

Brehm, J. O. and S. Gates (1997), Working, Shirking and Sabotage: Bureaucratic Response to a democratic Public (Ann Arbor: University of Michigan Press).

Dilulio; J. D., Jr and J. .J. DiIulio, Jr. (1994), "Principled Agents: The Cultural Bases of Behavior in the Federal Government Bureaucracy", Journal of Public Administration Research and Theory 4(3): 277-318.

Dimaggio, P. J., and W. W. Powell (1983) Institutional Isomorphism and Collective Rationality in Organizational Fields, American Sociological Review 48, 147-60.

Milward, H. Brinton, Laura Jensen, Alasdair Roberts, Mauricio I. Dussauge-Laguna, Veronica Junjan, René Torenvlied, Arjen Boin, H.K. Colebatch, Donald Kettl, and Robert F. Durant. "Is Public Management Neglecting the State?" Governance 29, no. 3 (2016): numnum.

Niskanen, W. (1971) Bureaucracy and Representative Government (Chicago:

Aldine/Atherton).

Perry, J. L. (1996), "Measuring public service motivation: an assessment of construct reliability and validity", Journal of Public Administration Research and Theory 6(1): 5-23.

Perry, J. L. (2000), "Bringing society in: toward a theory of public service motivation", Journal of Public Administration Research and Theory 10(2): 471-88.

Peters, B. G. (2011) Institutional Theory in Political Science: The New Institutionalism, $3^{\text {rd }}$. ed. (London: Continuum).

Pollitt, C. (2016) Advanced Introduction to Public Management and Administration (Cheltenham: Edward Elgar).

Selznick, P. (1957), Leadership in Administration: A Sociological Interpretation (Evanston, IL: Row \& Peterson). 
Vandenabeele, W., G. A. Brewer and A. Ritz (2014), "Past, Present and Future of Public Service Motivation Research", Public Administration 92(4): 779-89.

Waldo, D. (2007 [1948]), The Administrative State: A Study of the Political Theory of American Public Administration (Brunswick, NJ: Transaction Publishers).

Wilson, J. Q. (1989), Bureaucracy: What Government Agencies Do and Why They Do It (New York: Basic Books).
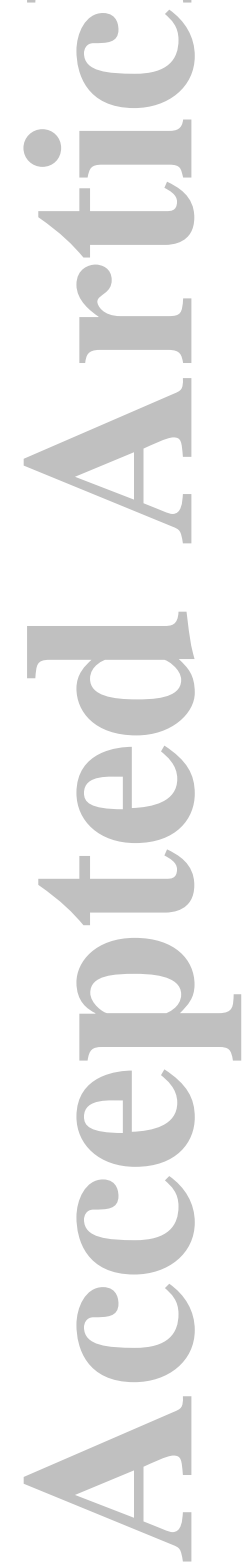


\section{University Library}

\section{- M M N E R VA A gateway to Melbourne's research publications}

Minerva Access is the Institutional Repository of The University of Melbourne

Author/s:

Peters, BG;Pierre, J

Title:

Two Roads to Nowhere: Appraising 30 Years of Public Administration Research

Date:

2017-01-01

Citation:

Peters, B. G. \& Pierre, J. (2017). Two Roads to Nowhere: Appraising 30 Years of Public Administration Research. GOVERNANCE-AN INTERNATIONAL JOURNAL OF POLICY ADMINISTRATION AND INSTITUTIONS, 30 (1), pp.11-16. https://doi.org/10.1111/ gove.12229.

Persistent Link:

http://hdl.handle.net/11343/291555 